\section{The Emergence of Chinese Businesswomen in Darwin, 1910-1940}

Natalie Fong

In a portrait taken in 1917, Selina Lee, the sixteen-year-old granddaughter of Northern Territory midwife Sarah Bowman and her merchant husband, Lee Hang Gong, poses somewhat awkwardly in traditional Chinese tunic and trousers, hair pulled back neatly (Figure 4.1, see p. 78). ${ }^{1}$ A portrait of Selina in a similar pose taken in the 1920s shows a more mature, pensive woman wearing a Western-style ankle-length dress (Figure 4.2). ${ }^{2}$ A decade later still, Selina has blossomed into Mrs Selina Hassan, who-wearing fashionable 'flapper' dresses, modern cheongsam and a permed bob-was now a widow, businesswoman, and secretary of the Darwin Kuomintang (KMT), supporters of the Chinese Republic and women's rights (Figure 4.3). ${ }^{3}$ The short hair (and unbound feet) of Chinese women of this time was, as historian Antonia Finnane has remarked, a visible 'symbol of liberation from the past and the patriarchy'.

In 1930 Selina was pictured alongside fellow KMT members congratulating English aviatrix Amy Johnson on her extraordinary solo flight from London to Darwin (Figure 4.4). Two years later, in a photograph taken at a KMT banquet to

Author's note: Thanks to the following for their assistance in the preparation of this chapter: Kate Bagnall, Julia Martínez, Fiona Paisley, Regina Ganter, Sophie Couchman, the Darwin Chung Wah Society, and the Northern 'Territory Archives Service. This chapter is based on two papers: 'The Emergence of Chinese Women Nor Territory, 1920-1950' 2018 Asia Pacific Economic and Business History as Entreprenes in Conference, Univesily of Tasmania, and 'Thding Her Sto Entrepreneurs in the Northern Territory, 1920-1950', 2018 International Australian Studies Association Conference, University of Queensland.

1. 'Selina L̇ee in Chinese Dress, 1917' (Selina Hassan Collection), in Chinese-Australian Historical Images in Australia (CHIA) [online database], Chinese Museum Collection, http://www.chia.chinesemuseum.com.au/ objects/D001057.htm.

'Selina Lee in Western Dress' (Selina Hassan Collection), in CHIA [online database], Chinese Museum Collection, http://www chia chinesemuseum.com.au/objects/D001058.htm.

'Presenting Address' (Chan Collection), in Northern Territory Library PictureNT [online database], http://

3. 'Presenting Address' (Chan Collection), in Northern Territory Library PictureN
www.territorystories,nt.govau/jspui/handle/10070/3408; 'Darwin Ladies, 1935 ' (Cheong Family Archives), in www.territorystories,nt.gov.au//jpui/handle/10070/3408; 'Darwin Ladies, 1935 ' (Cheong
CHIA [online database], http://www.chia.chinesemuseum.com.au/objects/D003684.htm.

4. Antonia Finnane, 'What Should Chinese Women Wear?: A National Problem', Modern China 22, no. 2 (1996), p. 114. commemorate the Darwin visit of the Chinese Consul General to Australia, Dr W. P. (Weiping) Chen, Selina is seated beside Dr Chen. ${ }^{5}$ She was given the distinction of delivering an address at the banquet in which she praised Chen and the KMT for promoting 'equality of opportunity' for Chinese women. ${ }^{6}$

The evolution of Selina Hassan between the 1910s and 1930s was emblematic of the modernization of Chinese women, particularly those in merchant families in early twentieth-century China and diasporic communities like Australia. Despite cultural expectations of being neither seen nor heard, some women became public figures, and some became businesswomen. Selina Hassan is among several remarkable Chinese businesswomen in the Northern Territory (hereafter 'the Territory') whose lives form the subject of this chapter.

Alanna Kamp, Kate Bagnall and Jan Ryan have all called for further examination of Chinese women's involvement in businesses in Australian history. ${ }^{7}$ This call is supported by historical statistics, earlier histories of Chinese Australian women, and the findings of this study, which demonstrate that Chinese Australian women were more actively involved in business than current scholarship suggests. Historian Catherine Bishop has written extensively about businesswomen in colonial Sydney, New South Wales, concluding that they were predominantly white. ${ }^{8}$ In considering Chinese businesses, Bishop noted that Chinese men 'were rarely accompanied by wives and families', and that non-European businesswomen are difficult to locate in records. ${ }^{9}$ In the early to mid-1900s, however, we see the emergence of Chinese businesswomen in Australia, particularly in the Territory.

There were few Chinese women in Australia during the colonial period, and thus few Chinese businesswomen. Many of the Chinese women who were in Australia had entered as wives, daughters, and servants of merchants, or were Australian-born daughters raised in merchant households. By the 1933 Commonwealth census, there were 3,137 Chinese or part-Chinese women in Australia. ${ }^{10}$ Their status as dependent females was not reflected in the census data. Of the 543 Chinese or part-Chinese women in Australia in employment (about 17 percent of Chinese or part-Chinese women in Australia), thirty-six stated they were employers. ${ }^{11}$ Elsewhere in the census, 773 Chinese women (or 24 percent of Chinese or part-Chinese women in

5. Julia Martínez 'Chinese Politics in Darwin: Interconnections between the Wah on Society and the Kuo Min Tang, in Chinese Australians: Politics, Engagement and Resistance, ed. Sophie Couchman and Kate Bagnall (Leiden: Brill, 2015), p. 258

6. 'Banquet by Kuo Min Tang, Northern Territory Times, January 19, 1932, p. 5.

7. Alanna Kamp, 'Chinese Australian Women's "Homemaking" and Contributions to the Family Economy in White Australia', Australian Geagrapher 49, no. 1 (2017), p. 17; Kate Bagnall, 'Rewriting the History of Chinese Families in Nineteenth-Century Australia', Australian Historical Studies 42, no. 1 (2011), pp. 62-77; Jan Ryan, Chinese Women and the Global Village (St Lucia, Queensland: University of Queensland Press, 2003), p. 27.

8. Catherine Bishop, Minding Her Own Business: Colonial Businesswomen in Sydney (Sydney: NewSouth, 2015), p. 19.

9. Bishop, Minding Her Own Business, pp. 19-20.

10. Census of the Commonwealth of Australia 30th June, 1933, part 12, Race (Canberra: Commonwealth Bureau of Census and Statistics, 1933), p. 901.

11. Census of Australia 1933, Race, p. 949 
Figures 4.1-4.4: The evolution of Selina Hassan (née Lee), 1917-1935.
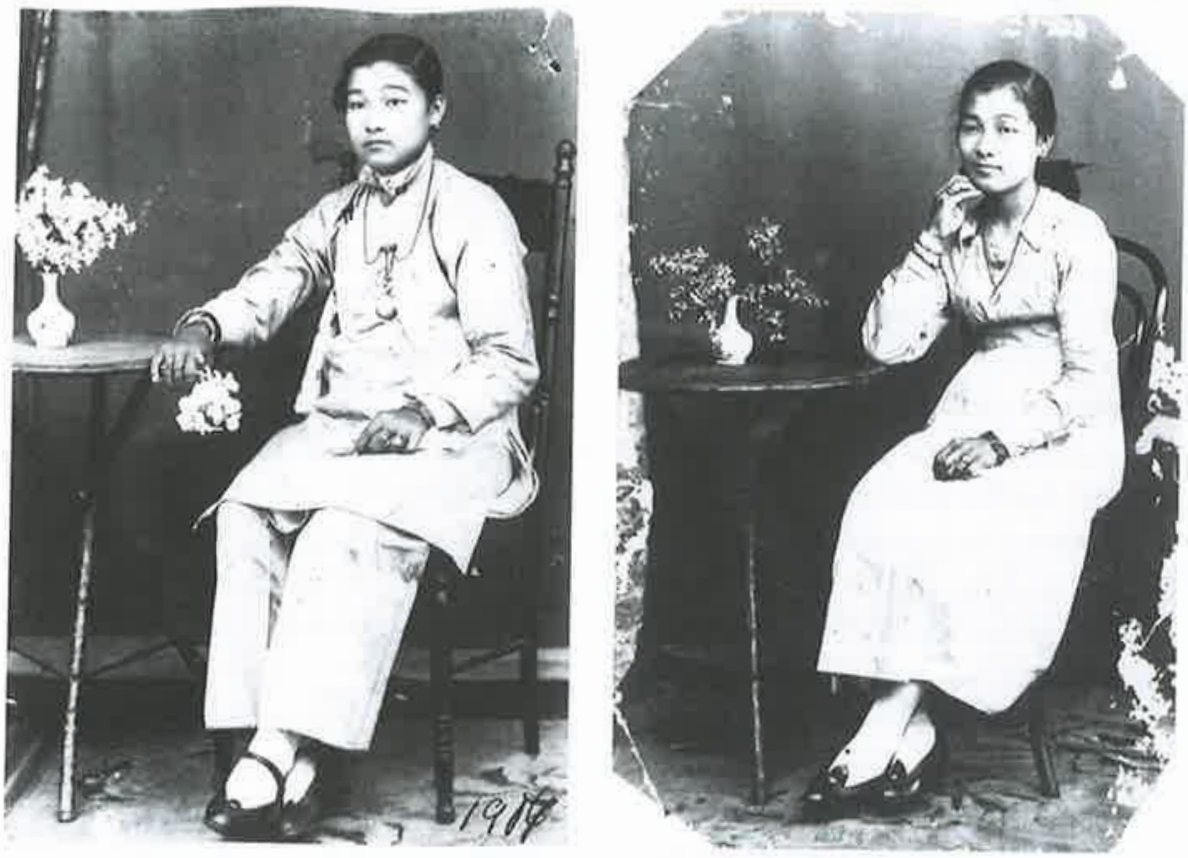

4.2: Selina Lee, c. 1920s.

4.1: Selina Lee, 1917.

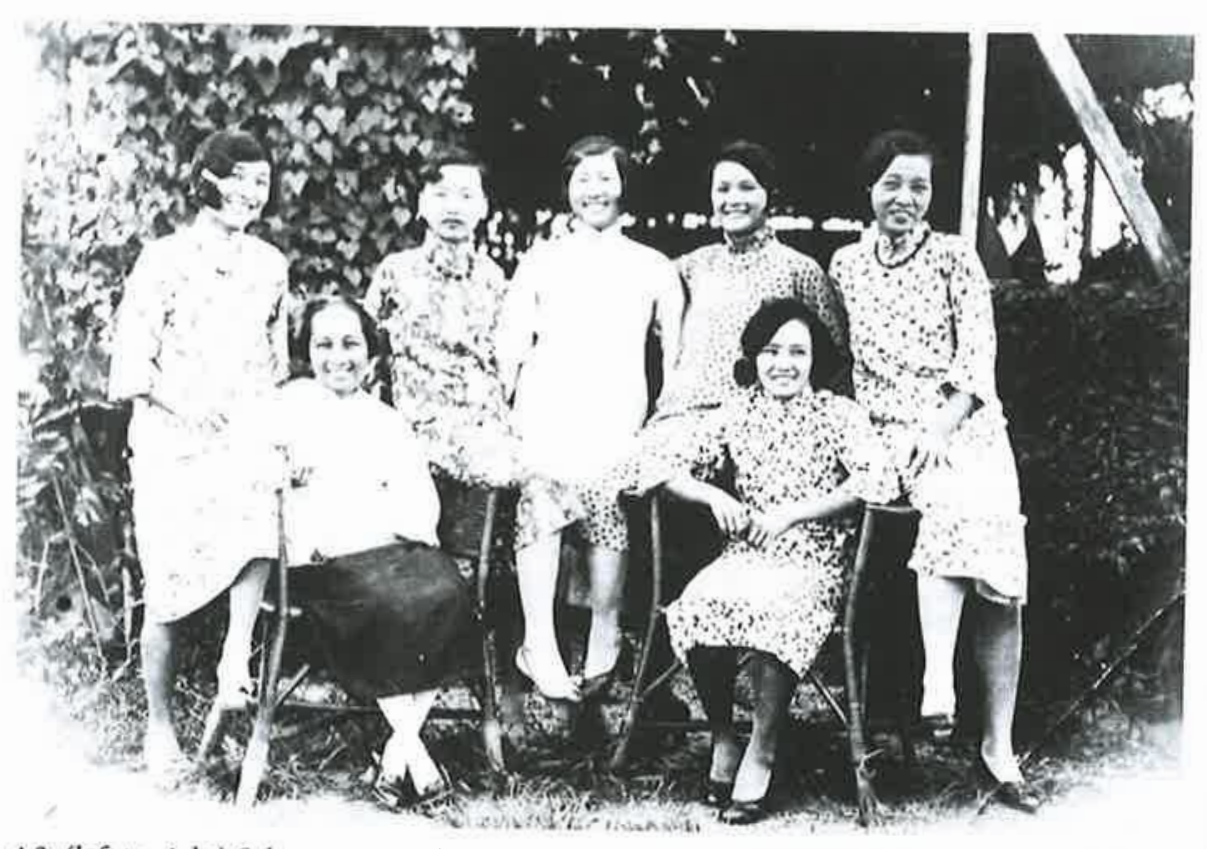

4.3: (left to right) Selina Hassan (née Lee), Ethel (Goot Ying) Cheong (née Lee; front), Ruby Hassan, Myrtle Houng On Yee (née Fong), unidentified, Pauline Chin (front), Mabel Ma
(née Lee), c. 1935.

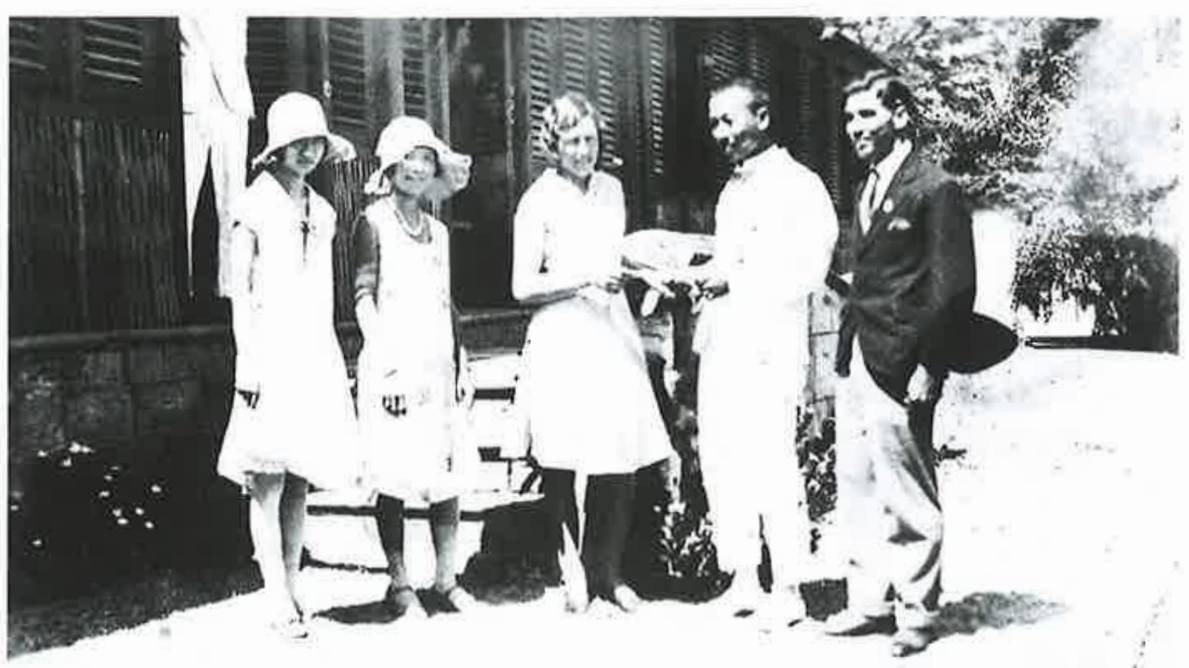

4.4: (left to right) Dolly Yuen, Selina Hassan (née Lee), Amy Johnson, Gee Ming Ket, Arthur Lee, 1930.

Australia) were identified as breadwinners. ${ }^{12}$ I would argue that Australian Chinese businesswomen are present in the archives and need unearthing. Alanna Kamp, Sophie Couchman, and Patricia Sumerling have identified Chinese Australian businesswomen in Sydney, Melbourne, and Adelaide, respectively, using sources such as newspapers, oral histories, immigration documents, and land ownership. ${ }^{13}$ As Kamp has noted, Chinese Australian wives were more than just 'crucial contributors' to family businesses; they may have been critical to businesses' survival, particularly after their husbands' deaths. ${ }^{14}$

Previous histories have drawn attention to 'noteworthy' Chinese women in the Territory as part of wider surveys on women (by Diana Giese and Barbara James) and Chinese (by Morag Loh, Glenice Yee, Regina Ganter, and Timothy Jones); Julia Martínez and Sophie Couchman have also discussed the politicizing of Territory Chinese women through the KMT. ${ }^{15}$ The significant role of Chinese women in busi-

12. Census of Australia 1933, part 28, Income, p. 1927.

13. Kamp, 'Chinese Australian Women's "Homemaking"'; Sophie Couchman, "Oh, I Would Like to See Maggie Moore Again!": Selected Women of Melbourne's Chinatown', in After the Rush: Regulation, Participation and Chinese Communities in Australia, 1860-1940, ed. Sophie Couchman, John Fitzgerald, and Paul Macgregor (Kingsbury, Victoria: Otherland Literary Journal, 2004), pp. 171-90; Patricia Sumerling, 'The Sym Choons of Rundle Street', Journal of the Historical Society of South Australia 41 (2013), pp. 81-88.

14. Kamp, 'Chinese Australian Women's "Homemaking", p. 13.

15. Diana Giese, Beyond Chinatown: Changing Perspectives on the Top End Chinese Experience (Canberra: National Library of Australia, 1995); Barbara James, No Man's Land: Women of the Northern Territory (Sydney: Collins, 1989); Morag Loh, 'Testimonies from White Australia: Oral History Interviews with Chinese Immigrants and Their Descendants', La Trobe Journal 90 (2012), pp. 112-24; Glenice Yee, Through Chinese Eyes: The Chinese Experience in the Northern Territory, 1874-2004 (Parap, Northern Territory: Glenice Yee, 2006); Regina Ganter, Mixed Relations: Asian-Aboriginal Contact in North Australia (Crawley: University of Western 
ness in the Territory has, until now, remained unexplored. As this chapter demonstrates, closer examination of archival material reveals the considerable involvement of Territory Chinese women in business, a traditionally patriarchal domain.

Various factors contributed to Chinese women's involvement in business in the Territory. Chinese merchants' wives and daughters were expected to assist in family businesses in domestic or manual roles. European businesswomen were active in the Territory when Chinese women arrived in the late nineteenth century, thus women running businesses was not an uncommon sight. In many cases the deaths of husbands and economic depression left wives with little choice but to work to support their families. Some Chinese merchants' widows were left with multiple children, including sons too young to manage family businesses, so widows became custodians of businesses or started businesses. In China, Sun Yat-sen, the KMT, and feminist movements promoted progressive attitudes towards women from the 1910s onwards. The involvement of young Darwin Chinese in the KMT may have encouraged couples to form business partnerships and women to register and run businesses in their own names. Some women ran businesses named after themselves.

When Australia is considered alongside China, America, Canada, New Zealand, and the Philippines, it is apparent that there were common socio-economic, cultural, and political factors that facilitated Chinese women's independence and involvement in business. ${ }^{16}$ Through collective biography, using ' individual lives to explore collective experiences' in a community, this chapter builds on existing studies by demonstrating the considerable documented participation of Chinese

Australia Press, 2006); Timothy G. Jones, The Chinese in the Northern Territory (Darwin: Charles Darwin University Press, 2005); Julia Martinez, Patriotic Chinese Women: Followers of Sun Yat-Sen in Darwin, Australia, in Sun Yat-Sen, Nanyang and the 1911 Revolution, ed. Lai To Lee and Hock Guan Lee (Singapore: Institute of Southeast Asian Studies, 2011), pp. 200-18; Martinez, 'Chinese Politics in Darwin', pp. 240-66; Sophie Couchman, 'Chinese Australian Brides, Photography and the White Wedding' (Chapter 3 in this volume).

16. See, for example, Chi-cheung Choi, 'Stepping Out? Women in the Chaoshan Emigrant Communities, 18501950', in Merchants' Daughters: Women, Commerce, and Regional Culture in South China, ed. Helen F. Siu (Hong Kong: Hong Kong University Press, 2010), pp. 105-27; Angelina Chin, Bound to Emancipate: Working Women and Urban Citizenship in Early Twentieth-Century China and Hong Kong (Lanham. MD: Rowman \& Littlefield, 2012); Huping Ling, Surviving on the Gold Mountain: A History of Chinese American Women and Their Lives (New York: State University of New York Press, 1998): Vivienne Poy Passoge to Promise Lan Voices of Chinese Immigrant Women to Conada (Montreat: McGill-Oueen's University Press, 2013), May Ip, Home Away from Home: Life Stories of Chinese Women in New Zealand (Auckland: New Women's Press, 1990): Ip 'From Gold Momen's Press, 1990); Ip, 'From Gold Mountain Women to Astronauts' Wives-Challenges to New Zealand Chinese Women; in Histories of the Chinese in Australasia and the South Pacific, ed. Paul Macgregor (Melbourne: Museum of Chinese Australian History, 1993), pp. 274-86; John T. Omohundro, Chinese Merchant Families in Iloilo (Quezon City, Metro Manila: Ateneo de Manila University Press, 1981); Richard T Chu, Chinese and Chinese Mestizos of Manila: Family, Identity, and Culture, 1860s-1930s (Leiden: Brill, 2010); Ruth Lam, Bevery Lowe, Helen Wong, Michael Wong, and Carolyn King, The Fruits of Our Labours: Chinese Fruit Shops in New Zealand (Wellington: Chinese Poll Tax Heritage Trust, 2018); Theresa C. Carino, 'Chinese Women in Manila; in More Tsinoy than We Admit: Chinese-Filipine Interactions over the Centuries, ed. Richard T. Chu (Quezon City: Vibal Foundation, 2015), pp. 463-77. women in business in the Territory, and the influence of circumstantial and contextual factors. ${ }^{17}$ As Maria Jaschok and Suzanne Miers comment:

The once ubiquitous stereotype of the long-suffering, meek, submissive Chinese woman as simply a victim of family interests, a vision of compliance and selfsacrifice, stands thus revealed for what it is-a stereotype in need of reappraisal and an empirical context. ${ }^{18}$

\section{Chinese Women in the Northern Territory: On Record}

The first major arrival of Chinese immigrants in the Territory occurred in 1874, two years after the first significant gold discovery at Pine Creek in 1872. The challenging climate and demand for cheap labour prompted South Australian authorities, who administered the Territory from 1863 until 1911, to contract 187 Chinese miners from Singapore in $1874 .{ }^{19}$ As news spread, more Chinese arrived via the credit-ticket system facilitated by Chinese merchants. The majority came from Guangdong, albeit from different dialect groups-Sze Yup (the majority), Heungshan, and Hakka. ${ }^{20}$ By 1881 the ratio of Chinese to Europeans in the Territory was reportedly six to one. ${ }^{21}$

Census data suggests that from the late 1800 s to the mid 1900 s the number of Chinese females in the Territory remained small, but the proportion of Chinese females to males increased over time. Table 4.1 (see p. 82) contains official figures for the Chinese population of the Northern Territory from 1881 to 1947. According to these figures, the population of Chinese females (classified by race not birthplace) grew significantly in the decades between 1881 and 1901 and between 1921 and 1933, then declined between 1933 and 1947. The population of Chinese males halved each decade between 1901 and 1947, contributing to the growing proportion of Chinese females to Chinese males. By 1947 the Chinese population in the Territory was about 60 percent male and 40 percent female-this proportion of Chinese females was higher than that in other Australian states. ${ }^{22}$

Legislative and economic factors contributed to the fluctuating numbers of Chinese in the Territory and the increasing proportion of Chinese females to males.

17. Krista Cowman, 'Collective Biography', in Research Methods for History, ed. Simon Gunn and Lucy Faire (Edinburgh University Press, 2011), p. 85.

18. Maria Jaschok and Suzanne Miers, 'Women in the Chinese Patriarchal System: Submission, Servitude, Escape and Collusion', in Women and Chinese Patriarchy: Submission, Servitude and Escape, ed. Maria Jaschok and Suzanne Miers (Hong Kong: Hong Kong University Press, 1994), p. 9.

19. Kathy De La Rue, 'Ruled by Remote Control: The Commonwealth's Role in the History of Darwin, 1911-1978' (PhD diss., Charles Darwin University, 2014), p. 63.

20. Agnes E. Hannan, 'All Outt: The Effects of Evacuation and Land Acquisition on the Darwin Chinese, 19411954' (BA Hons diss., Monash University, 1985), p. 17; Martinez, 'Chinese Politics in Darwin'; p. 242.

21. Shane Stone and Roger Steele, 'Progress of the Chinese Community of the Northern Territory', Northern Perspective 18, no. 1 (1995), p. 28.

22. In the other Australian states, the percentage of females in the Chinese population in 1947 was between 23.3 percent (South Australia, the lowest percentage) and 35.5 percent (Queensland, the highest percentage) (Census of the Commonwealth of Australia 30th Jume, 1947, part 15, Race [Canberra: Commonwealth Bureau of Census and Statistics, 1947], pp. 826-27). 
Table 4.1: Chinese in the Northern Territory, 1881-1941

\begin{tabular}{|c|c|c|c|c|c|c|}
\hline \multirow[t]{2}{*}{ Year } & \multirow[t]{2}{*}{$\begin{array}{c}\text { Total } \\
\text { NT } \\
\text { Population }\end{array}$} & \multirow{2}{*}{$\begin{array}{c}\text { Total No. } \\
\text { Chinese } \\
\text { (Full and } \\
\text { Part) }\end{array}$} & \multicolumn{2}{|c|}{$\begin{array}{l}\text { Chinese Males and } \\
\text { Percentage of 'Total } \\
\text { Chinese Population }\end{array}$} & \multicolumn{2}{|c|}{$\begin{array}{l}\text { Chinese Females and } \\
\text { Percentage of Total } \\
\text { Chinese Population }\end{array}$} \\
\hline & & & 'Full-Blood' & 'Half-Caste' & 'Full-Blood' & 'Half-Caste' \\
\hline 1881 & $4521 a$ & $3804 a$ & $\begin{array}{c}3800 \\
(99.9 \%)\end{array}$ & $b$ & $\begin{array}{c}4 \\
(0.1 \%)\end{array}$ & $b$ \\
\hline 1891 & 4898 & 3704 & $\begin{array}{c}3598 \\
(97.1 \%)\end{array}$ & $\begin{array}{c}46 \\
(1.2 \%)\end{array}$ & $\begin{array}{c}15 \\
(0.4 \%)\end{array}$ & $\begin{array}{c}45 \\
(1.2 \%)\end{array}$ \\
\hline 1901 & 4811 & 3120 & $\begin{array}{c}2962 \\
(94.9 \%)\end{array}$ & $\begin{array}{c}24 b \\
(0.8 \%)\end{array}$ & $\begin{array}{c}110 \\
(3.5 \%)\end{array}$ & $\begin{array}{c}24 b \\
(0.8 \%)\end{array}$ \\
\hline 1911 & 3310 & 1339 & $\begin{array}{c}1224 \\
(91.4 \%)\end{array}$ & $\begin{array}{c}4 \\
(0.3 \%)\end{array}$ & $\begin{array}{c}107 \\
(8 \%)\end{array}$ & $\begin{array}{c}4 \\
(0.3 \%)\end{array}$ \\
\hline 1921 & 3867 & 730 & $\begin{array}{c}609 \\
(83.4 \%)\end{array}$ & $\begin{array}{c}5 \\
(0.7 \%)\end{array}$ & $\begin{array}{c}113 \\
(15.5 \%)\end{array}$ & $\begin{array}{c}3 \\
(0.4 \%)\end{array}$ \\
\hline 1933 & 4850 & 480 & $\begin{array}{c}313 \\
(65.2 \%)\end{array}$ & $\begin{array}{c}13 \\
(2.7 \%)\end{array}$ & $\begin{array}{c}149 \\
(31 \%)\end{array}$ & $\begin{array}{c}5 \\
(1 \%)\end{array}$ \\
\hline 1947 & 10868 & 318 & $\begin{array}{c}154 \\
(48.4 \%) \\
\end{array}$ & $\begin{array}{c}38 \\
(11.9 \%)\end{array}$ & $\begin{array}{c}96 \\
(30.2 \%)\end{array}$ & $\begin{array}{c}30 \\
(9.4 \%)\end{array}$ \\
\hline
\end{tabular}

Notes: $a=$ Includes 1,070 Chinese, in transitu, on board vessels at Port Darwin; $b=$ Not available

Source: Commonwealth Bureau of Census and Statistics, Census (1933, 1947); Official Year Book (1925, 1973); Australian Data Archive, South Australia 1881 Census

South Australian and later Commonwealth legislation that regulated Chinese immigration did not specifically forbid the entry of Chinese women to the Territory. These laws also made exceptions for those who were economically desirable to authorities, particularly merchants, who facilitated trade between Asia and Australia, and their households. ${ }^{23}$ The earliest documented Chinese woman in the Territory that I have located is my great-grandmother Lie See (1874-1962). ${ }^{24}$ According to her World War II alien registration record, Lie See arrived in Australia in 1879 at age five, and

23. Sucheng Chan, 'The Exclusion of Chinese Women, 1870-1943', in Entry Denied: Exclusion and the Chinese Commumity in America, 1882-1943, ed. Sucheng Chan (Philadelphia: Temple University Press, 1991), p. 138; Madeline Yuan-yin Hsu, Dreaming of Gold, Dreaming of Home: Transnationalism and Migration Between the United States and South China, 1882-1943 (Stanford, CA: Stanford University Press, 2000), p. 95; Poy, Passage to Promise Land, p. 4; 'Sun Kwong Sing and Company - Part 2' (Department of Immigration, 1947-1950), National Archives of Australia (NAA): A2998, 1952/871.

24. 'Lie, See [Alien Registration File]' (Department of Immigration, Northern Territory Branch, 1942-1953), she is believed to have come to Australia as a mui tsai (妹仔 M: mèizăi). ${ }^{25}$ Mui tsai were 'little sisters' bought from poor families to serve as maids who, in the best of circumstances, were considered 'adopted daughters'; their masters usually arranged marriages for them when they were old enough. If these accounts and the census data are accurate, Lie See was one of the four Chinese females in the Territory in 1881. Historian Claire Lowrie notes that of the few early Chinese women in the Territory, some may have been mui tsai for merchants' families. ${ }^{26}$ Thus, in a sense, some of the earliest Chinese women in the Territory were employees.

The first law restricting the immigration of Chinese into the Territory was the South Australian Chinese Immigration Restriction Act 1888, which limited the number of Chinese passengers arriving by ship to one per 500 tonnes of shipping. While provision was made for resident Chinese to apply for exemption certificates, the South Australian parliament reserved the right to declare at any time which people or classes were exempted. ${ }^{27}$ Exemption categories were defined clearly in the later Coloured Immigration Restriction Act 1896 as including merchants, their families, and domestic servants. ${ }^{28}$ After Federation the Immigration Restriction Act 1901 introduced the notorious Dictation Test, with exemptions granted in the form of a Certificate of Domicile, a Certificate Exempting from the Dictation Test (CEDT), or a Certificate of Exemption. ${ }^{29}$ Exemptions again favoured merchants and their households, being primarily granted to those already 'domiciled' in Australia-for example, those who were Australian-born, owned land and property in Australia, had a permanent business address in Australia, or a wife and children resident there. ${ }^{30}$ 'The authorities' privileging of merchants and their households meant that the early Chinese women in the Territory, as in many overseas communities, were typically merchants' wives, daughters, or servants. ${ }^{31}$ Legislation regarding immigration and other matters such as employment disadvantaged labourers, who made up the bulk of the Chinese population, and many left the Territory (some were even repatriated to China). ${ }^{32}$ This contributed to the declining population of Chinese males from 1891 onwards, and the increasing percentage of Chinese females.

25. Barbara Fong, 'The Life and Times of Mary Sue Yook Fong nee Low' (unpublished manuscript in possession of the author, 2007)

26. Claire Lowrie, Masters and Servants: Cultures of Empire in the Tropics (Manchester: Manchester University Press, 2016), p. 157.

27. Chinese Immigration Restriction Act 1888 (SA).

28. Coloured Immigration Restriction Act 1896 (SA)

29. Immigration Restriction Act 1901 (Cth).

30. Kate Bagnall, 'Anglo-Chinese and the Politics of Overseas Travel from New South Wales, 1898 to 1925', in Chinese Australians: Politics, Engagement and Resistance, ed. Sophie Couchman and Kate Bagnall (Leiden: Brill, 2015), p. 208.

31. Cariño, 'Chinese Women in Manila', p. 463.

32. For a fuller discussion of how legislation affected the Chinese in the Northern Territory, see Natalie Fong, "Your Petitioners Will Ever Pray": Chinese Merchants and Organised Protest in the Northern Territory, 1880-1920' Limina 22, no. 2 (2017), pp. 31-47. 


\section{Documenting Chinese Women in Business}

Sources relating to Chinese women in the Territory demonstrate the significant involvement of at least several Chinese women in business. Chinese businesswomen feature in newspapers, land and business records, immigration documents, oral histories, wills, and photographs, and many of the richest sources are the result of events in the Territory during and after World War II. In 1942 and 1943 Darwin was bombed by Japanese forces, most brutally on February 19, 1942. Anticipating an attack, the government had evacuated women and children from Darwin from December 1941 to February 1942, which may explain the corresponding decline in the number of Chinese females. Businesses in the once-thriving Chinatown in central Darwin were badly damaged by bombs, looting, and fire. ${ }^{33}$ The federal government made rebuilding Darwin a major focus, acquiring all freehold land. Landholders could apply for compensation based on 1946 valuations, and buildings and improvements that existed before the bombings. Historian Michael Christie notes that of 491 town blocks acquired 106 were owned by Chinese..$^{34}$ Federal authorities used acquisition to minimize Chinese economic domination, with Territory Administrator Aubrey Abbott praising it as a means to 'entirely prevent the Chinese quarter from forming again. ${ }^{35}$ With authorities reclaiming prime commercial land and offering low amounts of compensation, many Chinese businesses closed or moved. Of twenty-five compensation claims made by Chinese that I have examined, fourteen involved women applicants, eight regarding businesses. ${ }^{36}$ Applicants contested the low compensation, involving much correspondence and taking years to reach unsatisfactory resolutions, but also leaving behind valuable sources regarding Chinese women and their business activities.

\section{Separate Spheres}

One way in which early Chinese women in the Territory were involved in business was behind the scenes of family firms. Chinese businesses began to be established in the 1880s in Palmerston (as Darwin was called until 1911) and elsewhere in the Territory. Typically, these businesses were headed by patriarchs, with male relatives as managers and shop staff-the public faces of businesses. By 1888 the overall Territory business landscape was dominated by Chinese merchants, and immigration concessions, technology (steamships, telegraphs), and transnational, transfamilial business networks allowed them to create 'Chinatown' in Cavenagh Street in central Palmerston. In 1888 Territory Police Inspector Paul Foelsche compiled a report on the Territory, an excerpt of which was published in the South Australian

33. Michael F. Christie, 'The End of Darwin's Chinatown', Northern Perspective 18, no. 2 (1995), p. 48

34. Christie, 'End of Darwin's Chinatown', p. 49.

35. Christie, 'End of Darwin's Chinatown', p. 49.

36. NT Darwin Freehold Acquisitions (Property and Survey Branch, 1932-1949), NAA; A877.
Register. Foelsche noted at least fifty-six Chinese businesses in Palmerston, including stores, carpenters, shoemakers, laundries, tailors, and eating houses; many imported goods and offered services for Chinese and European customers. ${ }^{37}$

The Chinese community was led and organized by merchant patriarchs who were often known by their business, rather than personal, names. These patriarchs had wives in the Territory, all Chinese with the exception of Sarah Bowman. Some key merchant patriarchs, their firms, and their spouses are outlined in Table 4.2 (see p. 86) and select family trees are provided in the Appendix. Key women discussed in the remainder of this study feature in these 'merchant bloodlines'. Most of these women had entered Australia as the wives of these merchant patriarchs. In Chinese culture, men having more than one wife, or wives and concubines, was accepted, and it was not uncommon for men in overseas communities such as Palmerston to have their first or principal wife in China in the ancestral village, and subsequent wives or concubines with them overseas. Territory-based merchants' wives were typically ten to thirty years younger than their husbands, which makes sense if they were subsequent wives.

Like Chinese merchants' wives in other overseas communities, public perceptions of the early Chinese women in the Territory were that they were sequestered in the private sphere of the home as housewives and mothers. ${ }^{38}$ Australian journalist Ernestine Hill visited Darwin in the 1930s and described Chinese women as having 'little freedom, spending their lives at the back of the shops and behind high tin walls, rearing innumerable babies', 'look [ing] out from behind barred windows', and being 'well-guarded. ${ }^{39}$ An obituary published in the Northern Standard in 1930 for Kim Que Chin, first wife of merchant Chin Gong, described how, 'like most of the Chinese women in Darwin, [she] was very retiring and seldom seen away from home.40

The seclusion of Territory Chinese women reflected customs in nineteenthcentury China, where Confucianism and feudalism bolstered patriarchy. In Chinese society, women were considered inferior to men. The Confucian ideal was that women followed the Three Obediences and Four Virtues: obedience to fathers, then husbands, then sons; and to "know her place in the universe, be reticent in words, be clean of person and habits . .., and fulfill her household duties.. ${ }^{41}$ Thus women needed little education. Many women, particularly of the upper class, were physically restricted by bound feet (although footbinding was not practised by the

37. 'The Chinese in the Northern Territory', South Australian Register, September 17, 1888, p. 1.

38. In Manila, merchants' wives were said to be 'hidden behind the windows of half-closed carriages' (Chu, Chinese and Chinese Mestizos, p. 200). In America, mission workers described merchants' wives as 'hemmed in by cultural prescriptions and by their own bound feet ... "very few of them are allowed to go on the streets" (Ling, Surviving on the Gold Mountain, p. 61).

39. Ernestine Hill, The Great Australian Loneliness (Sydney: Angus \& Robertson, 1940), p. 147; 'Aliens in Australia: How Chinese Live in Darwin', Advertiser, April 13, 1935, p. 16.

40. 'Death of Mrs Chin Gong', Northern Standard, June 13, 1930, p. 3.

41. Ling, Surviving on the Gold Mountain, p. 100. 
Table 4.2: Darwin Chinese merchant patriarchs, spouses, and firms, $1880 \mathrm{~s}$

\begin{tabular}{|c|c|c|}
\hline $\begin{array}{l}\text { Merchant Patriarch and } \\
\text { Date of Arrival }\end{array}$ & $\begin{array}{l}\text { Territory-Based Spouse, } \\
\text { Rank Number and Date of } \\
\text { Arrival (If Known) }\end{array}$ & $\begin{array}{l}\text { Name of Firm and Main } \\
\text { Business, Date Established }\end{array}$ \\
\hline $\begin{array}{l}\text { Chin Mee Leung (陳美良 } \\
\text { M: chén méiliáng), } 1882\end{array}$ & $\begin{array}{l}\text { Lum See } \\
\text { Wong See, } 1893\end{array}$ & $\begin{array}{l}\text { Wing Cheong Sing (㮡昌盛 } \\
\text { M: róng chāng shèng), tailors } \\
\text { and drapers, } 1883\end{array}$ \\
\hline $\begin{array}{l}\text { (Chin) Ah Cheong (陳龍祥 } \\
\text { M: chén lóngxiáng), } 1882\end{array}$ & Wong See, 1887 & $\begin{array}{l}\text { Sun Hing Kee (新錦記 } M: x \bar{i} n \\
\text { jin ji), merchants, grocers, } \\
\text { c. } 1885\end{array}$ \\
\hline $\begin{array}{l}\text { Chin Yam Yan (陳炎賢 } \\
\text { M: chén yánxián), c. } 1879\end{array}$ & Ah Ngoi & $\begin{array}{l}\text { C. Yam Yan and Company, } \\
\text { merchants and importers, } \\
1892\end{array}$ \\
\hline $\begin{array}{l}\text { Chin Toy (陳賸宜 } \\
\text { M: chén juànyí), } 1883\end{array}$ & Liew/Lew See & $\begin{array}{l}\text { Fang Cheong Loong (宏昌隆 } \\
\text { M: hóng chāng lóng), tailors, } \\
\text { drapers, goods, } 1886\end{array}$ \\
\hline $\begin{array}{l}\text { Fong How (鄺修榮 } \\
\text { M: kuàng xiūróng), } 1882\end{array}$ & $\begin{array}{l}\text { Young See (揚氏 M: yáng shi) } \\
\text { (2nd wife), } 1895\end{array}$ & $\begin{array}{l}\text { Wing Wah Loong (永和隆 } \\
\text { M: yǒng hé lóng), } \\
\text { storekeepers, importers, } 1882\end{array}$ \\
\hline $\begin{array}{l}\text { Lee Chow (李就 M: } / i \text { jiu), } \\
1879\end{array}$ & $\begin{array}{l}\text { Violet Fung (馮氏 C: fong } \\
\text { see, M: féng shi) (2nd } \\
\text { wife), } 1902\end{array}$ & $\begin{array}{l}\text { Man Fong Lau (萬芳樓 } \\
\text { M: wàn fáng lóu), grocers, } \\
\text { storekeepers, importers } 1886\end{array}$ \\
\hline $\begin{array}{l}\text { ee } \operatorname{Lim}(\text { 李霖 } M \text { : li lín), } \\
884\end{array}$ & $\begin{array}{l}\text { Moo Sue Quen (巫瑞群 } \\
\text { M: wū ruiqún), } \\
\text { Australian-born }\end{array}$ & $\begin{array}{l}\text { Wing Sang Tong (永生堂 } \\
\text { M: yǒng shēng táng), } \\
\text { importers, storekeepers, } \\
\text { c. } 1891\end{array}$ \\
\hline $\begin{array}{l}\text { uen Yet Hing (阮溢卿 } \\
\text { 1: ruăn yiqing), } \\
\text { 1877-78 }\end{array}$ & $\begin{array}{l}\text { Low See (3rd wife, } \\
\text { replacement for } 1 \text { st wife) }\end{array}$ & $\begin{array}{l}\text { Yet Loong (溢隆 M: yi lóng), } \\
\text { storekeepers, c. } 1888\end{array}$ \\
\hline
\end{tabular}

c. $1877-78$

Source: Compiled from Glenice Yee, Through Chinese Eyes: The Chinese Experience in the Northern Territory, 1874-2004 (Parap, Northern Territory: Glenice Yee, 2006); Sub-Collector of Customs, Darwin, National Archives of Australia: E752; Northern Territory Dictionary of Biography, revised edition (Darwin: Charles Darwin University Press, 2008); Shui Kwong Lo, From My Darwin Notebook and Chinese Temple or Joss House (Darwin: Northern Territory Archives Service Oral History Unit, 1989); 'Folder Containing (1) Index to Immigration Files (2) Miscellaneous Unregistered Correspondence' (Sub-Collector of Customs, Darwin, 1938), NAA: E758, INDEX ETC.
Hakka) and thus more limited in the work they could do. ${ }^{42}$ In the Territory, Low See (1880-1950), third wife of merchant Yuen Yet Hing, had bound feet. ${ }^{43}$ According to her youngest daughter Lilyan Chan (née Yuen, 1916-2006), who was born in Darwin, 'she couldn't do anything' except embroidery, so Yuen Yet Hing brought two mui tsai from China to do the housework. ${ }^{44}$ Young See (1879-1929), also my great-grandmother and wife of Fong How, arrived in Palmerston in 1895 with two mui tsai-Leung Tem Choy (1891-1938) and Lee Toy Kim (later known as 'Granny Lum Loy', 1891-1980). This suggests Young See also had bound feet. ${ }^{45}$ Despite bound feet, Young See travelled overseas three times between 1903 and 1920, for periods of one to three years, and both Low See and Young See became actively involved in businesses after the deaths of their husbands, as will be seen later in this chapter. ${ }^{46}$ And, although they began as mui tsai, Leung Tem Choy and Lee Toy Kim went on to run businesses and become matriarchs of well-known families. ${ }^{47}$ Chinese traditions did not prevent women from gaining agency.

Similar patriarchal limitations that kept Territory Chinese daughters at home suggest the guarding of sexual purity. Lilyan Chan reminisced that even until the 1920 s and 1930s girls 'were not allowed to go out anywhere'; they stayed inside and did needlework, with exceptions being Chinese New Year or if they were accompanied by their brothers. ${ }^{48}$ Nellie Fong (1916-1998) was the Darwin-born second daughter of Wong Quee and Chan Fon Yuen, a partner in Fang Cheong Loong. Her brother Harry married Lilyan Yuen and was elected Mayor of Darwin in 1966. As a young girl, Nellie delivered orders for Fang Cheong Loong and ran errands, but always accompanied by a male Aboriginal servant, Dilly. ${ }^{49}$ When Nellie turned thirteen, her mother told her to stay at home and work in the shop, 'because anything could happen to a girl. ${ }^{50}$ Nellie was still expected to contribute to Fang Cheong Loong by cleaning the shop and serving tea to the men, while her mother and aunts cooked for the men. ${ }^{51}$ The men ate in the shop, but the women had their meals

42. Ling, Surviving on the Gold Mountain, pp. 18-19.

43. Yee, Through Chinese Eyes, p. 12.

44. Lilyan Chan, interview by Diana Giese in the Post-war Chinese Australians Oral History Project [transcript], 1998, National Library of Australia: TRC 3684, p. 10

45. Lyn Fong, 'Fong Family Chronology' (unpublished manuscript in possession of the author, 2000), p. 24.

46. 'Fong How and Family - Chinese' (Northern Territory Branch Department of Immigration, 1917-1930), NAA: E37, 1967/265.

47, After Lee Toy Kim's husband died, she leased four hectares of land in Darwin in 1920, establishing a mango plantation and exporting produce to Western Australia (Agnes F. Hannan, 'Lee Toy Kim [Mrs Lum Loy]', in Northern Territory Dictionary of Biography, revised edition [Darwin: Charles Darwin University Press, 2008] p. 338). When Leung Tem Choy's husband contracted tuberculosis in the mid-1920s, she ran the family's store in Pine Creek and learned to bake bread and brew hop beer to sell. This business was continued by son Jimmy Ah Toy and his wife, Lily, and their descendants until 2015 (Ellen Cramond, interview by Margaret Gillespie, 1986, NTAS Oral History Unit: NTRS 226/P0001/33, TS 483).

48. Lilyan Chan, interview by Diana Giese, pp. $8,12$.

49. Nellie Fong, interview by Diana Giese in the Post-war Chinese Australians Oral History Project [transcript], 1996, National Library of Australia: TRC 3543, p. 5.

50. N. Fong, interview, p. 4.

51. N. Fong, interview, p. 14. 
at home. ${ }^{52}$ Chinese women in Sydney and Canada had similar supporting roles in family businesses. ${ }^{53}$

Chinese traditions and customs did not preclude women from the world of work. While Hill's observation of Territory Chinese women being kept at the back of shops may have been accurate, her remark that the Chinese women were just 'rearing innumerable babies' was not. ${ }^{54}$ In the Territory, as in other Chinese communities, residences were typically behind or above businesses, thus women could move between the private sphere of the home and the public sphere of the business unobserved from the street. ${ }^{55}$ Hence the perception that they rarely left home. Scholars have found that in China in the early twentieth century women worked to contribute to household economies in various ways. In certain communities in southern China, for example, women who worked as silk labourers went through a 'delayed transfer marriage' because of the value of their labour outside the family. ${ }^{56}$ Even women with bound feet could work from home to support their families-for example, by weaving. ${ }^{57}$

Sewing was a flexible form of employment for immigrant women, allowing them to fulfil domestic duties while contributing to the family's income..$^{58}$ When Nellie Fong's father died, she and her mother learned to sew trousers, buttonholes, and buttons as further assistance to the business and to earn money. Nellie was paid ten shillings per week. ${ }^{59}$ Mrs Sue Wah Chin (1901-2000), daughter-in-law of Chin Toy, sewed up to six pairs of shorts or trousers a day for Fang Cheong Loong, for which she was paid fifteen shillings-more than the general manager. This encouraged other women to take up sewing work..$^{60}$ American and Canadian Chinese women also earned incomes by working in family businesses or starting home-based businesses. ${ }^{61}$

52. N. Fong, interview, p. 14 .

53. Kamp, 'Chinese Australian Women's "Homemaking"', pp. 8-9; Yuen-Fong Woon, 'Between South China and British Columbia: Life Trajectories of Chinese Women', BC Studies 156/157 (2007/2008), p. 87.

54. Hill, 'Aliens in Australia', p. 16.

55. See, for example, maps in acquisition compensation claims: 'NT Darwin - Freehold Acquisition 17 January 1946 - Claim of Chin Gong - Holding No 97, 253, 330' (Property and Survey Branch, 1946-1952), NAA A877, CL24151; 'NT Darwin Freehold Acquisition 17 January 1946 - Claim of Chin Loong Pak - Holding No 91, 101, 133, 173, 249, 335' (Property and Survey Branch, 1946-1956), NAA: A877, CL24272.

56. Adam McKeown, 'Transnational Chinese Families and Chinese Exclusions, 1875-1943', Journal of American Ethnic History 18, no. 2 (1999), pp. 99-100.

57. Melissa J. Brown, Laurel Bossen, Hill Gates, and Damian Satterthwaite-Phillips, 'Marriage, Mobility and Footbinding in Pre-1949 Rural China: A Reconsideration of Gender, Economics, and Meaning in Social Causation, Journal of A sian Studies 71, no. 4 (2012), p. 1041

58. Ling, Surviving on the Gold Mountain, pp. 70-71.

59. N. Fong, interview by Giese, pp. 8, 17.

60. Raymond Chin, interview by Diana Giese in the Post-war Chinese Australians Oral History Project [transcript], 1996, National Library of Australia: TRC 3542.

61. Early Chinese women immigrants in America worked in laundries, restaurants, and grocery stores (Ling. Surviving on the Gold Mountain, p. 51). So did Chinese Canadian women, often living in the same building; or working from home doing baking and sewing (Multicultural History Society of Ontario, 'School and Work, Chinese Canadian Women, 1923-1967: Inspiration - Imnovation - Ingenuity, accessed February 26, 2018. http://www.mhso.ca/chinesecanadianwomen/en/exhibit.php? $\mathrm{e}=59$ ).

\section{Entering the Public Domain: Merchant Widows}

By the 1930s several Chinese businessmen's wives and daughters had fully emerged into the sphere of work in public positions. The photograph Group of Darwin Ladies, taken around the late 1940s to early 1950s, depicts two generations of these Chinese women (Figure 4.5, see p. 90). ${ }^{62}$ In the front row are four matriarchs who had outlived their businessmen husbands, including Chin Wong See, who had owned and managed a business herself. Behind them stand Myrtle Houng On Yee and the Selina Hassan mentioned at the beginning of this chapter-both of whom ran businesses in Darwin. Freed from some Chinese cultural restrictions by the deaths of husbands and with evolving attitudes towards women, from the late 1910s wives and daughters became more actively involved in business as custodians of family businesses, co-workers with husbands, or heads of their own businesses. ${ }^{63}$

In China and diasporic Chinese communities such as Darwin, Chinese wives experienced increasing independence and involvement in businesses owing to the absences of their merchant husbands. Merchants' absences, whether temporary (due to business) or permanent (due to death), left their wives to oversee households and family businesses. In Guangdong, wives were involved in the buying and selling of land using remittances from husbands or sons abroad. ${ }^{64}$ Thus, the absence of emigrant husbands may have 'sparked the inevitable rise of female power in China' as women assumed headship of households. ${ }^{65}$ In Canada, and in the Philippines from around the 1950s, an increasing number of Chinese women outlived their husbands and took the reins of their husbands' businesses, ensuring continuity. ${ }^{66}$ John Omohundro has commented that in Iloilo in the Philippines, Chinese business matriarchs were thus able to gain agency both in the business arena and in the home, helping to raise the status of women. ${ }^{67} \mathrm{~A}$ similar argument can be made about Northern Territory Chinese widows.

Territory Chinese women were able to become more actively involved in business in an environment generally conducive to the involvement of women in business. Historic trade between Indigenous people in the Territory's north, Chinese, and Southeast Asians, together with initially relaxed immigration regulations, resulted in polyethnic communities. Morag Loh has suggested that the 'flexible and pragmatic' society of Darwin allowed women greater independence. ${ }^{68}$ Women 62. 'Group of Darwin Ladies' (Shu Ack Fong Collection), in PictureNT [online database], Northern Territory
Library, http://hdl.handle.net/10070/35560.

63. To date, Sarah Bowman is the earliest Chinese merchant's wife known to have worked, and she did so while her husband was alive. She was a well-known midwife and advertised herselfave worked, and she did so while steamship travellers (Yee, Through Chinese Eyes, p. 7; 'Notice', Northern Trself as a stewardess or lady's maid for 1882 , p. 2).

64. Choi, 'Stepping Out?', pp. 108-10; Hsu, Dreaming of Gold, p. 118; Michael Williams, 'In the Tang Mountains We Have a Big House, East Asian History 25/26 (2003), p. 92

. Choi, 'Stepping Out?', p. 112

66. Woon, 'Between South China and British Columbia', p. 88.

67. Omohundro, Chinese Merchant Families in lloilo, p. 145.

68. Loh, 'Testimonies from White Australia', p. 119. 


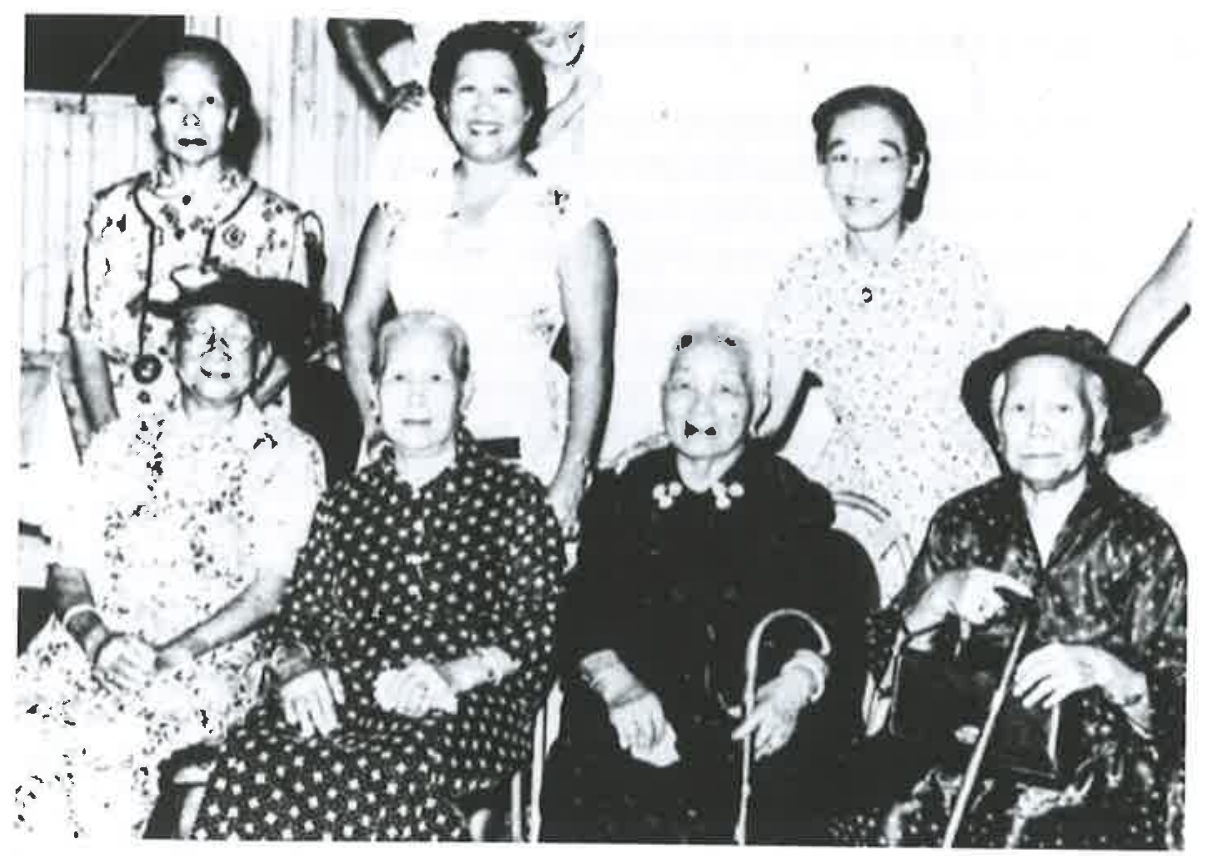

Figure 4.5: 'Group of Darwin Ladies', c. 1950. Back row (left to right): Chan Fon / Chin Fong, Myrtle Houng On Yee (née Fong), Selina Hassan (née Lee). Front row (left to right): Mrs Fong Ding (Wong See), Mrs Chin Toy ('Granny Quong'), Mrs Lowe Dep (Lie See), Mrs Chin Mee Leung (Wong See).

Shu Ack Fong Collection, Northern Territory Library (PH0497/0020)

also gained financial independence and protection with the 1883 South Australian Married Women's Property Act. From the 1870 s Territory women were working as hoteliers and publicans, conducting educational establishments, managing cattle properties, and running stores, boarding houses, and eateries. ${ }^{69}$ Women were accepted, even respected, as owners and managers of businesses. So when Chinese women began arriving in the Territory from the 1880 s, businesswomen were already a familiar sight.

From the 1910s to the 1940s several key Chinese merchant patriarchs in the Territory died, some unexpectedly. The age gap between merchants and their younger Territory-based wives made it likely that women would outlive their husbands. These widows were often left with a number of children in a country whose

69. 'Opposite the Bank, Palmerston', NTTAG, April 17, 1874, p. 2; 'British \& Foreign Hotel; NTTAG, November 17, 1874, p. 1; Barbara James, 'Ryan, Ellen', in Northern Territory Dictionary of Biography p. 510 ; 'Victori Hotel, Darwin', Northern Standard, December 30, 1921, p. 4; 'Victoria Hotel, Darwin', NTTAG, November 30 , 1926, p. 4; 'Palmerston Academy, Cavenagh Street', NTTAG, May 8. 1874, p. 1; 'Northern Territory Times', NTTAG, April 10, 1874, p. 2; Helen J. Wilson, 'Cox, Matthew Dillon', in Northern Territory Dictionary of Biography, p. 118; 'The Cafe Canberra', NTTAG, July 10, 1928, p. 3; 'Francesca Bleeser', Northern Standard. January 6, 1928, p. 5; 'Pioneer Store and Eating House, Union', North Australian, July 28, 1888, p. 2. language they might not have spoken fluently. In many cases their sons were too
young to inherit, or were absent on war service or for education in China Some widows became custodians of businesses and properties until their sons could assume responsibility. Some were appointed by their husbands as executrices of estates, suggesting their husbands recognized their financial and business skills. Some widows even started their own businesses. These women overcame various challenges in order to provide for their families, legacies sadly reduced by the bombing of Darwin and consequent compulsory acquisition.

Chin Wong See (1875-1960) was the wife of Chin Mee Leung (Chin June) of Wing Cheong Sing. When Chin Mee Leung died in 1914, he left a shop on Cavenagh
Street to his widow to be held in Hen's 1947 claim for compen the executor of his estate. ${ }^{70}$ In Chin Ark on which this shop stood insation for the Commonwealth acquisition of the land Filipino, Kanada, who was killes noted that the shop had been let as a dwelling to a rental income from tha killed during an air raid in 1942. ${ }^{71}$ In addition to deriving rental income from this property, Ivan Simon, Darwin Sub-Collector of Customs, owner, and for some the Department of the Interior that Chin Wong See was the her husband management of the business management of the business to her son, Chin Loong Pak. ${ }^{33}$

When Low See's husband, Yuen Yet Hing of Yet Loong, died suddenly in 1916, Yet Loong began advertising as 'Yet eldest, Ernest, was seven. From February 1918 ment Low See had in of her bound feet. Low See 'shop of Mrs Yet Low See owned a business managed by Moo Fatt, probably the 'shop of Mrs Yet Loong's' advertised in the Northern Standard as the retailer of E. renting out a shop ${ }^{\prime 5}$ She also owned property, including a lot on Cavenagh Street, Ack Fun for non- and a house on this land; in 1933 she successfully sued Charlie for land on Cavenagh Street, rent ${ }^{76}$ According to her 1946 compensation claim Yean Ying \& Co., Bakers; Ed, there had been five businesses on the lot, inding an estimation of the lor's Edwin Verburg [sic], grocers; and Mrs Yet Loong. ${ }^{77}$ As an estimation of the lot's value, the compensation applied for was $£ 10,980$, but

Holding Nin - Frechold Acquisition 17-1-1946 - Claim of Chin Pound Nam and Estate of Chin June Holding No 251' (Property and Survey Branch, 1946-1953), NAA: A877, CL24250.

71. NAA: A877, CL24250.

72. 'Foider Containing (1) Index to Immigration Files (2) Miscellaneous Unregistered Correspondence' (SubCollector of Customs, Darwin, 1938), NAA: E758, INDEX ETC

73. NAA:E758,

74. 'Yet Loong \& Sons', NTTAG, February 2, 1918, p. 16.

1934, p. 9 .

Standard, September 22, 1933, p.1. p. 8; 'The Federal Parliament to Reassemble on September 27', Northern

77. NT Darwin- Fechos

Survey Branch, 1946-1954), NAA: A877, CL24147. 
three years later Low See was awarded $£ 3,800 .^{78}$ She passed away the following year (1950), having appointed daughters Lucy Lee and Rose Moo Fatt as executrices of her estate-recognition of the worth of daughters. ${ }^{79}$

Like Low See, Young See's husband, Fong How of Wing Wah Loong, died unexpectedly while in China in 1920, leaving her with eleven children. ${ }^{80}$ Albert, the eldest male child then in Darwin, was twelve. Young See, as 'Mrs Wing Wah Loong', seems to have assumed leadership of her family and providing for her children, even though she may have had bound feet and was literate only in Chinese (she signed documents in Chinese characters一揚氏) ${ }^{81}$ In 1923 she placed a newspaper advertisement offering lot 564 on Mitchell Street for lease-'for particulars, apply Mrs Wing Wah Loong.8. cordial factory. Young See purchased the lot next to Wing Wah Loong and set up a general store, Fong Yuen Kee, in $1924 .{ }^{83}$ She moved her family into the residence at the store's rear. ${ }^{84}$ Young See reportedly established this business as an inheritance for her sons. ${ }^{85}$ Soo Kee stated after Young See's death that she had told him she was the registered owner of Fong Yuen Kee and her son, Albert, was managing it for her. ${ }^{86}$ In 1946, Albert Fong, now a leading member of the KMT and Chinese Commercial Society and the first president of the Chung Wah Society, submitted compensation claims estimating the value of the land on which stood Fong Yuen Kee Brothers and Bakers and Wing Wah Loong as £25,550, and lot 564 Mitchell Street (Fong Yuen Kee cordial factory) as $£ 5,620 .{ }^{87} \mathrm{He}$ was awarded $£ 10,957$ in total for these claims. ${ }^{88}$

In 1925 Violet Fung (1886-1958) also lost her husband, Lee Chow of Man Fong Lau, to a sudden illness, leaving her with eight children. The business, Man Fong Lau, was $£ 25,000$ in debt at the time. ${ }^{89} \mathrm{~A}$ decade later, in 1935, 'Mrs Lee Chow' remained the proprietress of Man Fong Lau, with her sons assisting. She depended on the living from the business; selling fruit and sweets brought in thirty to fifty

\section{NAA: A877, CL24147. \\ 79. NAA: A877, CL24147.}

80. 'Certificate of Exemption from Dictation Test - Fong How' (Sub-Collector of Customs, Darwin, 1919-1920), NAA: E752, 1919/50).

81. NAA: E37, 1967/265.

82. 'To Let on Lease', NTTAG, October 27, 1923, p. 5.

83. 'Leung Kee - Application to Enter Commonwealth Assistance Fong Yuen Kee Bros' (Sub-Collector of Customs, Darwin, 1940-1941), NAA: E756, 63.

84. Edward Fong, 'My Autobiography' (unpublished manuscript in possession of the author, 1985), p. 3 .

85. Lyn Fong, 'Chinese Merchants and Matriarchs of Colonial Australia' (unpublished manuscript in possession of the author, 2004), p. 12

86. 'See, Youn' [probate file] (Supreme Court of the Northern Territory, 1929), Northern Territory Archives Service (NTAS): NTRS 3623/P0001/1, 21/1929.

87. 'NT Darwin - Freehold Acquisition 17 January 1946 - Claim of Albert Fong Goon - Holding No 167 and 359' (Property and Survey Branch, 1946-1957), NAA: A877, CL24238; 'NT Darwin - Freehold Acquisition 17 January 1946 - Claim of Fong Kam Lam, Albert Fong Goon and Fong Gang Ming - Holding No 420' (Property and Survey Branch, 1946-1957), NAA: A877, CL24328.

88. NAA: A877, CL24238; NAA: A877, CL24328

89. 'Death of Lee Chow', NTTAG, May 29, 1925, p. 3. shillings gross per week. ${ }^{90}$ Like other widows, she took in a boarder at ten shillings per month. ${ }^{91}$ In 1935 Mrs Lee Chow was charged with selling liquor without a licence. In the court case, it was noted that she did not have a good command of English; she testified through an interpreter. ${ }^{92} \mathrm{Mrs}$ Lee Chow gave several justifiable reasons as to why she had alcohol on her premises. ${ }^{93}$ Despite witnesses also stating that she did not sell them liquor, Mrs Lee Chow was fined $£ 50$ in default of imprisonment. ${ }^{94}$ The stewardship of Man Fong Lau by Mrs Lee Chow and her sons ensured its survival until the bombing of Darwin in 1942.

Mrs Moo Sue Quen (1898-1963), widow of Lee Lim of herbalists Wing Sang Tong, was the executrix of his estate when he died in $1940 .{ }^{95} \mathrm{He}$ gave her his 'right title and interest as a partner in the firm of Wing Sang Tong' and the land on which the shop was built. After the settling of debts, however, his estate was only valued at $£ 441 .{ }^{96}$ Moo Sue Quen had advantages over other merchants' wives: she was Australian-born and educated in English, signing documents with an English signature ('Moo Sue Quen'). ${ }^{97}$ Her stewardship of the estate is evident in her applications for compensation for the acquisition of Lee Lim's properties. On these holdings had been several businesses in addition to Wing Sang Tong. The total amount requested, the largest of the claims by Chinese women I have examined so far, was $£ 44,180$. The government offered $£ 8,136$. After three years and much correspondence, the claims were settled for $£ 13,250 .{ }^{98}$ Moo Sue Quen pleaded for quicker processing as she was in 'urgent need of the advances to finance her ex-servicemen sons in business in Darwin. ${ }^{99}$ When she died in 1963 she left an ex-servicemen sons in business her interest as a partner in the family's Lee Transport Company worth $£ 3,733$ to one son, Lee Bing Chow. ${ }^{100}$
90. 'Appeal Case - Koop v. Lee Chow' (Northern Territory Crown Law Office, 1935), NAA: E72, DL494, p. 24.

NAA: E72, DL494, p. 25.

2. NAA: E72, DL494, p. 8

3. NAA: E72, DL494, pp. 21-22.

94. 'Police Court', Northern Standard, April 26, 1935, p. 9.

95. 'NT Darwin Freehold Acquisition 17 Jnuary 19 ?

Quen - Holding No 252, 357,362' (Propert 1946 - Claim of Estate of Lee Lim - Executor Mrs Moo Sue Darwin Freeherty and Survey Branch, 1946-1949), NAA: A877, CL.24316: NT Darwin Fechold Acquisition 17 January 1946 - Claim of Estate of Lee Lim - Executor of Est 24te Mrs No Sue Quen - Holding No 291 and 362' (Property and Survey Bron

96. 'Lee Lim' [probate file] (Supreme Court of the Northen Branch, 1947-1950), NAA: A877, CL24315. $39 / 1940$. Quen' (Sub-Collotion fest - Moo Sue 8. NAA:

99. NAA: A877, CL24315; NAA: A877, CL.24316.

99. NAA: A877, CL.24316

100. 'Sue Quen Lee' [probate file] (Supreme Court of the Northern Territory, 1965), NTAS: NTRS 3624/P0001/19, Agents]' (Register of Coor 


\section{Thoroughly Modern 'Missus': Merchant Daughters}

Evolving attitudes towards women worldwide from the late 1800 s meant that subsequent generations of women had greater access to education and work than their forebears. In China the early 1900s saw the rise of the anti-imperialist, modernizing Republican movement and the KMT, and the formation of women's rights groups, but also the beginning of the Great Depression. Revolutionaries believed the evolution of society depended on improving the position of women. ${ }^{101}$ Dr Sun Yat-sen's call for equality for all, jiěfäng (解放, 'emancipation') and particularly fünứ jiěfàng (媂女解放, 'emancipation of women'), emphasized by the May Fourth Movement (1917-1921), spawned campaigns in China such as anti-mui tsai protests, education for women, and the end of footbinding. ${ }^{102}$ The Chinese in Darwin kept abreast of Chinese politics and the majority of business owners appears to have been proRepublican. In 1911, when news broke of the Republicans' triumph in China, the Republican flag appeared in 'all the Chinese business premises.' ${ }^{103}$

This pro-Republicanism meant that some Territory Chinese families were supportive of women being educated; legislation also mandated schooling for children. The South Australian Education Act 1875 and Northern Territory Education Ordinance 1917 made schooling compulsory for children aged seven to thirteen and six to fourteen, respectively, so merchants' daughters attended local schools and were instructed in English. ${ }^{104}$ In 1927 at Darwin Convent School, Dolly Yuen came second in the sixth class, while Sarah Fong topped the fourth class; in 1940, Mavis Moo was the dux of Darwin Public School. ${ }^{105}$ Education enabled women to gain clerical work in Darwin. ${ }^{106}$ Lena Pak Fong (1902-1930), daughter of Ah Ngoi and Chin Yam Yan, was Australian-born but educated in Hong Kong. ${ }^{107}$ At the time of her death, she had been working as a bookkeeper at Yuen See Kee's. ${ }^{108}$ Alice Gum, daughter of San She (Ah Gow) (1873-1931) and Gum Fong Sing of the Sun Hop Lee laundry and store, was working as a bookkeeper at Carey and Company (once

101. Maria Jaschok, 'Chinese "Slave" Girls in Yunnan-Fu: Saving (Chinese) Womanhood and (Western) Souls, 1930-1991', in Women and Chinese Patriarchy, ed. Jaschok and Miers, p. 172.

102. Ibid

103. 'The Chinese Revolution, NTTAG, November 24, 1911, p. 2.

104. Education Act 1875 (SA); under the Education Ordinance Act 1917 (NT), children aged six to nine had to attend school if schools were within two miles of their residence, and between nine and fourteen years if schools were within three miles of their residence. A secondary school operated in Darwin from 1921 to 1925 (the only one in the Territory), but closed owing to low enrolments; secondary schools began operating again in the 'Territory from 1948 (Ted Ling, 'Education', Commonwealth Government Records about the Northern Territory (Canberra: National Archives of Australia, 2011), http://guides.naa.govaa/ records-about-northern-territory/part2/chapter13/13.2.aspx).

105. 'Convent School', Northern Standard, December 16, 1927, p. 2; 'Peace in Pacific: Friendly Trade Essential', Northern Standard, January 26, 1940, p. 8.

106. For examples of daughters working for family businesses, see: Ip, Home Away from Home, p. 57; Kamp, 'Chinese Australian Women's "Homemaking", p. 11.

107. Martínez, 'Patriotic Chinese Women', p. 204.

108. 'Inquest on Mrs Lena Lee', Northern Territory Times, January 24, 1930, p. 6. owned by her sister, Mary Yamamoto, discussed below) in 1939, and lived on site. ${ }^{109}$ Similarly, in New Zealand in the 1940s and 1950s, Chinese daughters who excelled academically worked in administrative roles in businesses. ${ }^{110}$

One of the earliest documented Territory Chinese businesswomen is Mary Yamamoto (Mao Chun Gum, 1899-?). Mary was Australian-born and married to Japanese storekeeper Tsunematsu Yamamoto. In her 1918 CEDT, she gave her occupation as 'storekeeper and housewife'; it is not known what business she was operating at that time. ${ }^{111}$ In 1924 Mary purchased the Kwong Tung Café in Cavenagh Street, and in 1927 she acquired Carey and Company, Bakers, also in Cavenagh Street. ${ }^{112}$ Her 1935 CEDT stated that her husband and children were domiciled on Thursday Island. ${ }^{113}$ The reason for this domestic situation and its influence on Mary's business operations or vice versa is unclear.

Founded in 1924, the Darwin KMT put into practice new ideas about women and many of the young Chinese in Darwin were active members; according to Martínez, by 1925 its executive members were all aged between twenty and thirty. ${ }^{114}$ They advocated the participation of women, and in 1927 Lena Pak Fong, now Lena Lee after her marriage to Willie Lee (brother of Selina Hassan), and Selina Yuen (daughter of Yuen See Kee) were members of the KMT committee that welcomed a Prince of Siam to Darwin. This was reportedly the first time Chinese women participated in an Australian public function. ${ }^{115}$ In 1929 Lena became secretary of the KMT and attended the KMT conference in Sydney as a Darwin delegate. ${ }^{116}$ Tragically, she took her own life in 1930. Lena's sister-in-law Selina Hassan (19011996), who was featured at the beginning of this chapter, served as KMT secretary from 1931 to 1932. In Selina Hassan's aforementioned speech to the Chinese Consul General to Australia, Dr W. P. Chen, at a KMT banquet in 1932, she proclaimed:

Equality of opportunity is all China wants ... China with her great natural wealth and her countless patriotic men and beautiful women will very quickly take her rightful place as the greatest power in the world... The Chinese women are even more patriotic than the men. ${ }^{17}$

109. 'Firm Registration File, Carey and Co. [Bakers]' (Register of Companies, 1935-1944), NTAS: NTRS 245/ P0019/1, Firm 24; 'Indecent Assault: Aboriginal Charged', Northern Standard, November 7, 1939, p. 12

110. Ip, 'From Gold Mountain Women to Astronauts' Wives', p. 279.

111. 'Certificate of Exemption from Dictation Test - Mary Yamamoto' (Sub-Collector of Customs, Darwin, 1918-1919), NAA: E752, 1918/17.

112. 'Notice', NTTAG, April 8, 1924, p. 3; 'Carey and Co - Application Admission of Chinese Assistant [George Gum]' (Sub-Collector of Customs, Darwin, 1941), NAA: E757, 1.

113. 'Certificate of Exemption from Dictation Test - Mary Yamamoto' (Sub-Collector of Customs, Darwin, 1935), NAA: E752, 1935/8.

114. Martinez, 'Chinese Politics in Darwin', p. 240; Martínez, 'Patriotic Chinese Women', p. 200.

115. 'Darwin Kuo Min Tang's Welcome to Prince of Siam', Northern Territory Times, July 12, 1927, p. 1.

116. Martinez, 'Chinese Politics in Darwin', p. 251.

117. 'Banquet by Kuo Min Tang', p. 5. 
Perhaps reflecting the KMT's egalitarianism, some young KMT couples formed business partnerships. ${ }^{118}$ Before her marriage to Charlie Houng On Yee, Myrtle worked for her brother George Lim in See (1880-1961) and miner Fong Ding, and bakery in Mataranka with and Charlie Houng On Yee ran a lauer brother, Charlie On. ${ }^{119}$ Together Myrtle Cavenagh Street, Darwin. ${ }^{20}$ When Lucy and sold bicycles as 'M. Houng-On' in the aforementioned Low See and Yuen Yet Hinée Yuen, 1909-1986, daughter of claim for compensation for the goven Yet Hing) and her husband, Willie, made a land in 1946, Willie was described as a squisition of their Cavenagh Street the time of their claim they were proprietorchant', with Lucy as joint tenant. At Chin (1912-1981, daughter of Chin Krietors of a café in Maroubra, Sydney. ${ }^{121}$ Lily Charlie On in 1932. ${ }^{122}$ In 1946 she Kwong-Leung of Kwong Hai laundry) married Darwin, where there had been a made a claim for compensation for land in Parap, made by Lily because the title was in herfice, and residence. While the claim was Draper, Tailer, Grocer.'123

There were two Territo

Gladys Sym Choon (described women with KMT affiliations who, like Adelaide's own businesses in their own names and styled importer in Adelaide'), had their they heralded themselves as successors to merchemselves as merchants. ${ }^{124}$ Thus, were daughters, not sons. One of these women Hassan.

\section{Selina Hassan}

Family circumstances may have contributed to Selina Hassan's independence and Kong-born Emily Louie (1868-1935) in 1901 in Darwin, the daughter of Hong preter Arthur Lee Hang Gong (born and businessman, police constable, and interthey resided in Creswick, Victoria). In Sarah Bowman and Lee Hang Gong when to Hong Kong, where Arthur Lee Hang 1904 Arthur, Emily, and their family moved have the KMT twelve-point star on their headstones in Darwin General Cemetery (photographs held by also
author). 119. 'Weddin

Lan)' in Northern Territory Dictionary of Biography, p. 293.

120. Yee, 'Houng On Yee, Myrtle', p. 294; 'The Fiography, p. 293.

1941, p. 9.
121. 'NT Darwin Freehold Acquisition 17 Jal

Holding No 283' (Property and Survery Branch, 1946-1950), NAA: A877 Lee, Lucy Lee (as Joint Tenants) -

122. 'Chinese Wedding: On-Chin', Northern Standard, November 15, 1932, p. CL24231.

123. NT Darwin Freehold Acquisition 17 January 1946 , November 15, 1932, p. 1.

Survey Branch, 1946-1954), NAA: A877, Cl24334; 'Charlie On' Northern Stang No 575' (Property and p. 8.

124. Sumerling, 'The Sym Choons of Rundle Street', p. 86.

to Darwin with one son; Selina and two of her brothers went to live in Guangdong with their father's second wife, reuniting with their mother in Darwin in 1910, when Selina was around nine. Selina attended her ailing grandmother, Sarah Bowman, until Sarah's death in 1911, after which Selina attended school. Emily set up a tripe soup business with another Chinese woman and also sold snacks and soft drinks to support her family. ${ }^{125}$ Selina returned to China when she was eighteen to marry businessman Ali Hassan, a Chinese Indian Muslim born in Hong Kong who had gone to Australia as a crew member of a pearl lugger. The couple settled in Darwin.

When Ali Hassan died suddenly in 1929, leaving Selina with three young children, she worked to support her family. Ali Hassan had, however, left Selina the bulk of his estate, about $£ 1,000$, and in 1927 and 1928 he had transferred ownership to her of two lots on Cavenagh Street, on which stood their residence and several businesses. ${ }^{126}$ Widowed Selina was therefore not without resources, but in an interview in 1979 she said she had to work because the Depression hit and there was no rent coming in, and they did not already have a family business for her to work in or manage. ${ }^{127}$ She set up a tailoring and car hire business with Charlie Houng On Yee; Selina recalls, 'I was the leader.'21 Like other (male) Chinese business owners, in 1930 she placed a notice in the Northern Territory Times advising that she would soon be absent from Darwin; her brother, Willie, would 'receive all moneys owing and payable', accounts for car hire were to be paid to Alfred Jan. ${ }^{29}$ In 1932 she opened her own store, S. Hassan and Co., registered as 'tailors and merchants', in Cavenagh Street. ${ }^{130}$ It presented as mercantile, advertising as 'Denizens of the Jungle', as they imported rubber goods from Singapore. ${ }^{131}$ The business was unsuccessful. ${ }^{132}$ Selina Hassan also had mining interests-in 1934 she was approved for a gold-mining lease for twenty acres in Fletchers Gully in the Territory. ${ }^{133}$

In 1938 Selina married Hamdan Bin Mahomed Amid, a Malayan indentured pearling seaman, in Darwin. At the completion of her husband's indenture, he was ordered to leave Australia, so he moved to Singapore. He was joined there in 1940 by Selina and her children by Ali Hassan, Allan and Connie. During the Japanese occupation, they were compulsorily domiciled in a Malayan kampong. Daughter Connie married Malayan-born Omar Jauhari in 1944. After the war, with the help of her solicitor in Australia, Selina applied for compensation for the acquisition

125. Selina Hassan, interview by Barabara James [transcript], 1979, NTAS: NTRS 226/P0001/14, TS 236, pp. 3-7. 126. 'Hassan, Ally (Ali)' [probate file] (Supreme Court of the Northern Territory, 1929) NTAS: NTRS 3623/
P0001/1, 23/1929.

127. Selina Hassan, interview by Barbara James [transcript], p. 15

128. Hassan, interview, p. 22.

129. 'Notice', Northern Territory Times, December 9, 1930, p. 3. For similar notices of other Chinese storekeepers, see, for example, Wee Wat Lew, 'Public Notice', NTTAG, January 31, 1896, p. 2; Lee Cheong Quong, 'Public
Notice', NTTAG, April 20, 1906, p. 2 .

130. 'S. Hassan \& Co.' Northern Standard, July 22, 1932, p. 7; 'Firm Registration File, S Hassan and Company
[Tailors and merchants]' (Register of Companies, 1935-1963), NTAS: NTRS 245/P091/, Firm [Tailors and merchants]' (Register of Companies, 1935-1963), NTAS: NTRS 245/P0019/1, Firm 27.

131. 'Denizens of the Jungle: At Home at Hassans; Northern Standard, February 17, 1933, p. 9.

132. Hassan, interview, p. 23 .

133. 'Mining Leases', Northern Standard, November 9, 1934, p. 10 
of her Darwin land, estimating its value as $£ 13,450$, including several businesses and her residence. ${ }^{134}$ She was offered $£ 3,575$. In the ensuing negotiations, Selina explained that the property had been her 'only means of livelihood ... [assuring her] of a regular rental income of $£ 51$ per month' Having been compulsorily domiciled, she was in financial difficulties and poor health. ${ }^{135}$ The claim was eventually settled in 1949 for $£ 5,292 .{ }^{136}$

In 1947 Selina applied for the entire family to be allowed to settle in Australia, which authorities permitted with the exception of Hamdan Bin Mahomed Amid and Omar Jauhari, fearing it would set a precedent. Jauhari was admitted temporarily on a student visa, as he and Connie had a child, with another on the way. Selina then tried another approach-in 1936 she had proposed a live-cattle export scheme between Darwin and Singapore, with the assistance of a pastoralist and the support of the then Acting Minister for the Interior. ${ }^{137}$ Now that the war was over, and with her husband unable to return to Australia, she asked whether she could at least have her son-in-law assist her in establishing this scheme? MP for the Northern Territory Macalister Blain wrote to the Minister for Immigration, Arthur Calwell, urging him to consider Selina's proposal and making reference to historical precedent-that is, the administration of the Immigration Restriction Act 1901, which frequently made exceptions for Chinese merchants, who facilitated trade between Asia and Australia, and their staff. The minister was unmoved. ${ }^{138}$ Jauhari did end up residing permanently in Australia, but Selina and Amid divorced in Singapore, and Amid remained there while the rest of the family returned to Australia. ${ }^{139}$ Selina continued to support herself and her family through businesses and other means in Victoria. She died in 1996.

\section{Lorna Lim}

Lorna Lim (née Lowe, 1904-1982) was the Territory-born daughter of Lie See and market gardener and blacksmith Lowe Dep. In 1921 she married tailor George Lim, son of Wong See and miner Fong Ding, in Pine Creek. George and Lorna's exact involvement in the KMT is not known; however, both have the KMT star on their headstones, as does Wong See, George's mother, ${ }^{140}$ Historian Mei-fen Kuo notes that this was generally an honour bestowed with Party approval. ${ }^{141}$ In 1926 they moved to Katherine, where they and their family, which eventually included

134. 'NT Darwin Freehold Acquisition 17 January 1946 - Claim of Selina Hassan - Holding No 244' (Property and Suvery Branch, 1946-1949), NAA: A877, CL24137.

135. NAA: A877, CL24137.

136. NAA: A877, CL24137.

137. NAA: A877, CL24137.

138. 'Hassan - Selina and Others' (Department of Immigration, 1946-1957), NAA: A446, 1954/61282

139. Suzette Pedersen, correspondence with the author, August 27, 2019.

140. Photographs held by the author-

141. Mei-fen Kuo, correspondence with the author, June 15, 2018 five daughters and four sons, ran a store, bakery, and peanut farm. ${ }^{1 / 2}$ In 1938 they moved to Darwin, and that year Lorna purchased Jessop and Company, tailors and general storekeepers, and was advertised as proprietress. ${ }^{143}$ This was the first Chinese business in Smith Street, the European economic area of Darwin. ${ }^{1+4}$ The business imported fresh fruit and vegetables and was granted the tender to supply produce to hospitals and other government institutions in Darwin. ${ }^{15}$ From 1940 the company traded as 'Lorna Lims', although the West Australian newspaper reported that it was George Lim 'trading as Lorna Lim. ${ }^{146}$ George and Lorna's son, Alec Fong Lim (who was elected Mayor of Darwin in 1984), said that George was assisted by his wife and children in building a 'thriving business.' ${ }^{147}$ In Lorna Lim's compensation claim for the acquisition of their Smith Street property, she stated that she was the title holder because 'she had previously conducted the business', and in the claim she listed her occupation as 'merchant.' ${ }^{148}$ The amount of compensation she requested was $£ 8,900$; she was initially only offered $£ 5,935$. The claim was settled in 1949 for $£ 6,700{ }^{149}$

During the war, the Lim family was evacuated to Alice Springs where they ran a shop, tailoring business, and tearoom with a gross annual income of over $£ 7,000.150$ The Lims returned to Darwin in 1946, and again established a store in Smith Street-'Lorna Lim and Sons'; 'Lorna Lim and Sons' also became proprietors of the Victoria Hotel. ${ }^{151}$ According to Alec Fong Lim, the store was actually run by Lorna and her daughters and 'could not have survived without them', while George and his sons ran the Victoria Hotel. ${ }^{152}$ The Lims' daughters registered their own business in 1958-Lim Sisters, storekeepers in Smith Street. ${ }^{153}$ The Lims sold the Victoria Hotel to Carlton and United Breweries in 1965 for $£ 400,000$. 142. Alec Fong Lim, interview by Sandra Saunders [transcript], 1981, NTAS Oral History Unit: NTRS 226/
P0001/13, TS 211, p. 2.

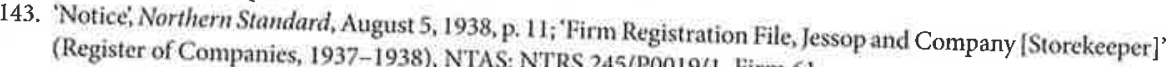
44. Alec Fong Limpanies, 1937-1938), NTAS: NTRS 245/P0019/1, Firm 61.

145. 'Jessop \& Company', Nowthen Stra Saunders [transcript], p. 4.

29, 1938, p. 8. 29,1938, p. 8

46. 'Lorna Lims', Northern Standard, May 17, 1940, p. 9; 'Darwin Melee: AIF Men in Riot', West Australian,
September 3, 1941, p. 5 .

48. NT Fong Lim, interview by Sandra Saunders [transcript], p. 5.

(Property and Surery Acquisition 17 January 1946 - Claim of Lorna Lim - Holding No 275, 324, 349 149. NAA: A877, CL.24359.

(2.

50. 'Trading Results - Lorna LIM \& George LIM, Alice Springs - Tailors and Drapers' (State Deputy Prices Commissioner, South Australia, 1942-1946), NAA: AP5/1, 1944/3662.

1946-1963), NTAS: NTRS 245/Pim and Sons [Drapers, grocers and hotelkeeper]' (Register of Companies, p. 3.

152. Alec Fong Lim, interview by Sandra Saunders [transcript], p. 11 .

53. Firm Registration File, Lim Sisters [Storekeepers]' (Register of Companies, 1958-1963), NTAS: NTRS P0019/17, Firm 1092 


\section{Conclusion}

The Australian Chinese women in this study traversed the boundaries of separate spheres-public and private, work and home-as they had increasing opportunities to work in business over the first half of the twentieth century. The proliferation of set a precedent for in the Northern Territory in the late nineteenth century had women were a commone creating an environment in which businesswere members of sight. While most of the earliest Chinese women in Darwin they contributed to family businesses and were largely confined to the home, labour in sewing and un their unseen Despite Chinese businesses being domestic tasks such as cooking and cleaning. widows became hearchants died by the Depression in the families and businesses. Economic necessity, exacerbated involvement in business in the Territory.

In the early twentieth modern attitudes towards womenr, increased access to education in English and and the KMT further en wo hemotican movement, ees and employers in their and encouraged Territory women to become employdomestic sphere to work in family busineschant daughters were able to leave the businesses after themselves and their own. By naming Lorna Lim represented a new calling themselves merchants, Selina Hassan and turies-old trades previously the preserve of Chinese women, revolutionizing cengender equality.

prater As the approach of collective biography taken by this study and others men-
ioned reveals, there are common in business in China, Australia, New Zef Chinese women's growing participation century, and Canada this broader scholarship and to recent in later decades. This study contributes to ness, such as that by Alanna Kamp work on Australian Chinese women in busiof archival materials to ness involvement in the Northern the nature and extent of Chinese women's busithe kinds of documenter Norritory. This study also provides examples of be found. Hopefully, it will prompt more be conducted of Chinese bumpt more sources to be located and further studies to challenge understandings about and including more enterprising racialized and gendered spaces of home and work,

\section{Appendix: Selected Darwin Family Trees}

Chinese wives were often known by their maiden family surname + 氏 (C: $\operatorname{sih} ; \mathrm{M}$ : shi), meaning 'clan' or 'family'.

Women's names in bold indicate those discussed in this chapter. An ordinal number (e.g. 2 nd, $3 \mathrm{rd}$ ) in front of a woman's name indicates her position as second
or subsequent wife. Names marked with an asterisk $\left(^{*}\right)$ indicate those with known Kuomintang
(KMT) affiliation.

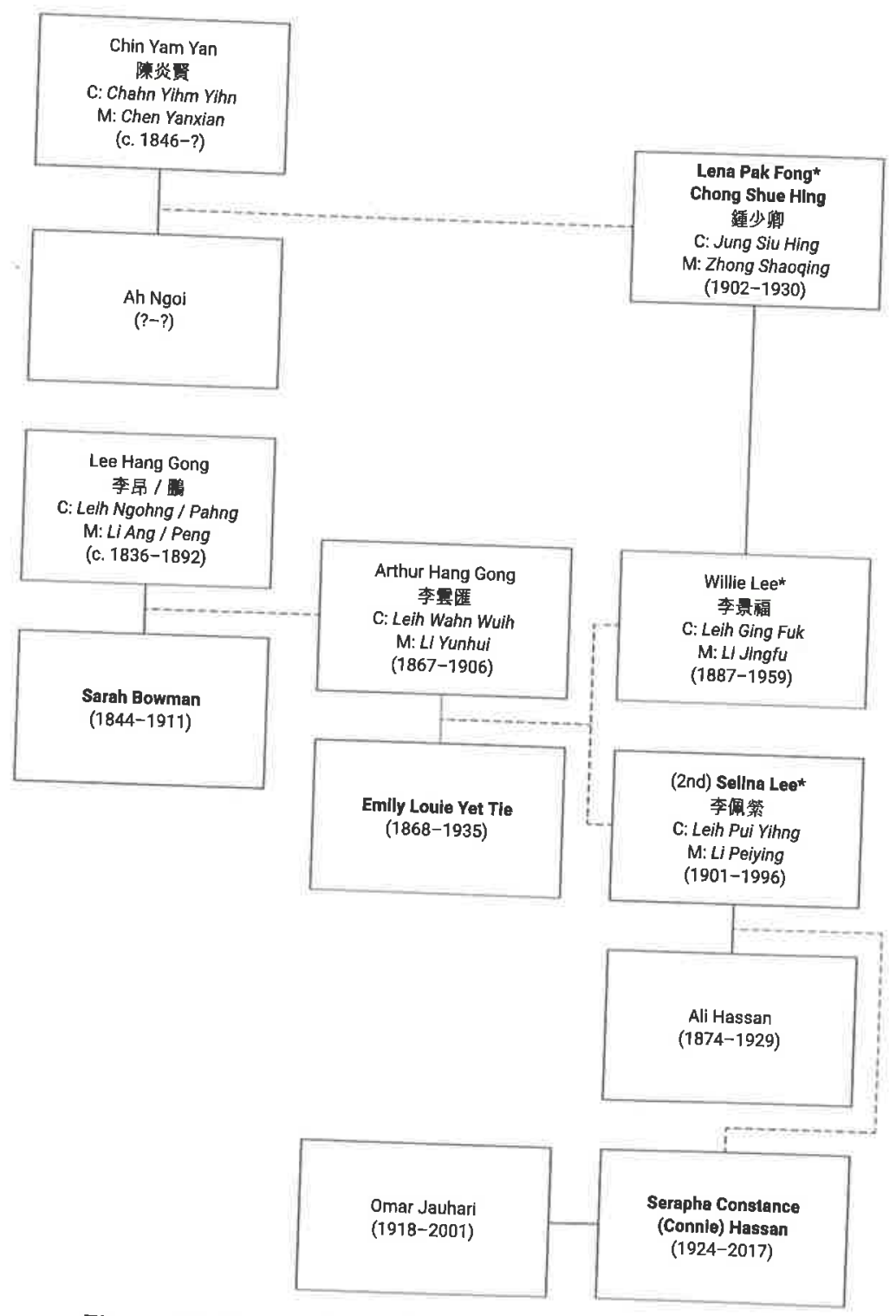

Figure 4.6: The families of Chin Yam Yan and Lee Hang Gong. 

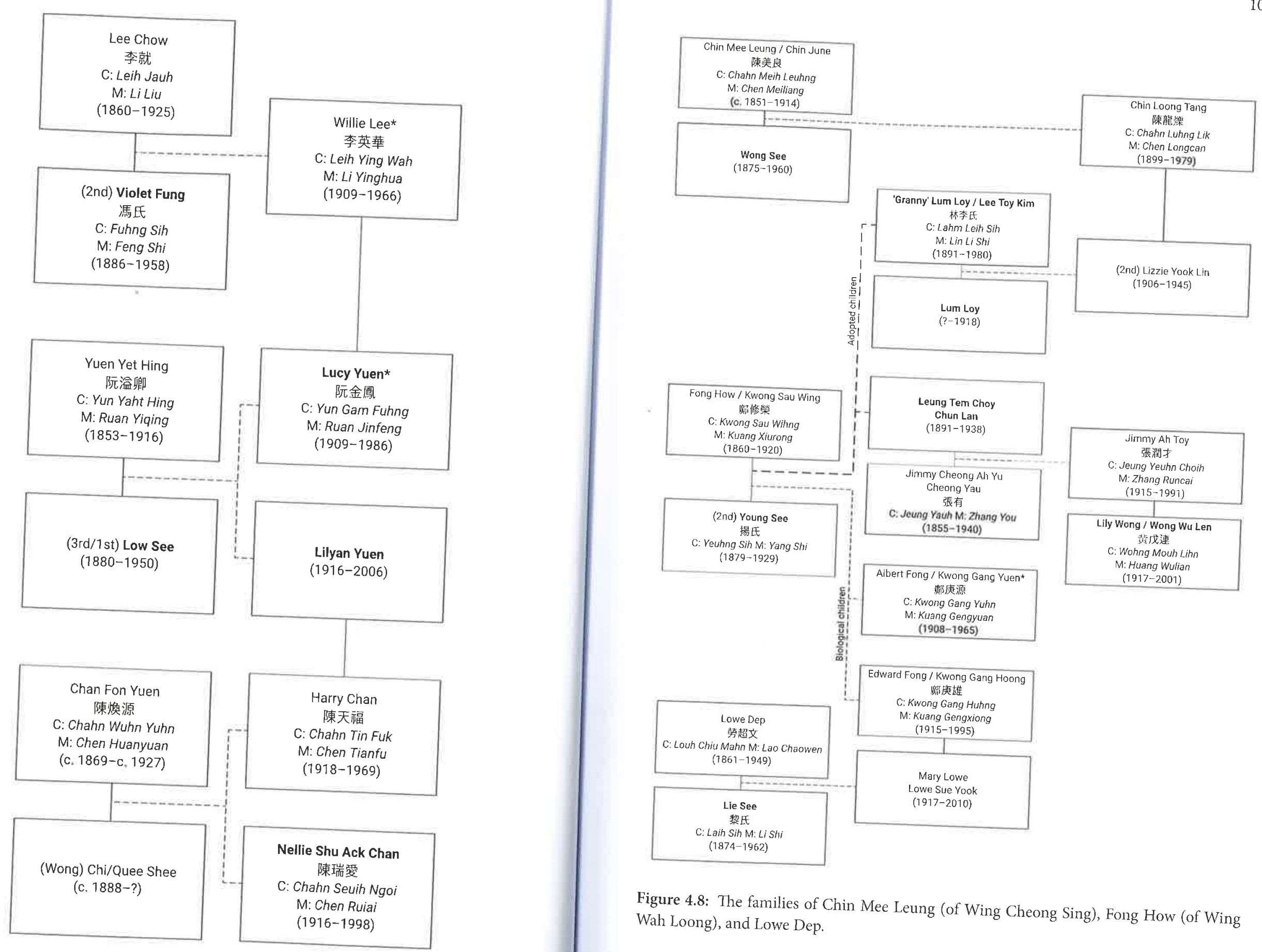

Figure 4.8: The families of Chin Mee Leung (of Wing Cheong Sing), Fong How (of Wing
Wah Loong), and Lowe Dep. Figure 4.7: The families of Lee Chow (of Man Fong Lau), Yuen Yet Hing (of Yet Loong), and
Chan Fon Yuen (of Fang Cheong Loong). 


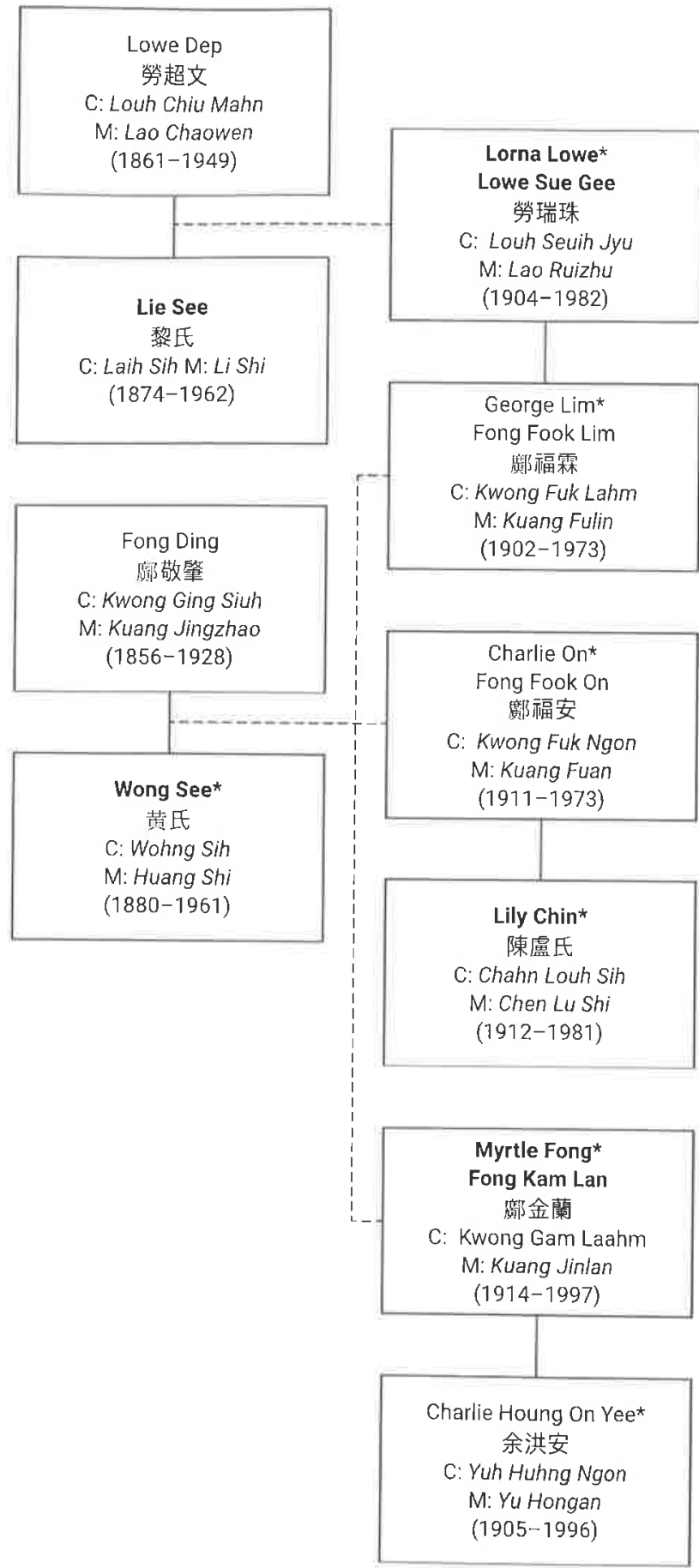

Figure 4.9: The families of Lowe Dep and Fong Ding. 